\title{
Effects of Exercise and Aging on Skeletal Muscle
}

\author{
Giovanna Distefano ${ }^{1}$ and Bret H. Goodpaster ${ }^{1,2}$ \\ ${ }^{1}$ Translational Research Institute for Metabolism and Diabetes, Florida Hospital, Orlando, Florida 32804 \\ ${ }^{2}$ Sanford Burnham Prebys Medical Discovery Institute, Orlando, Florida 32827 \\ Correspondence: bret.goodpaster@flhosp.org
}

A substantial loss of muscle mass and strength (sarcopenia), a decreased regenerative capacity, and a compromised physical performance are hallmarks of aging skeletal muscle. These changes are typically accompanied by impaired muscle metabolism, including mitochondrial dysfunction and insulin resistance. A challenge in the field of muscle aging is to dissociate the effects of chronological aging per se on muscle characteristics from the secondary influence of lifestyle and disease processes. Remarkably, physical activity and exercise are well-established countermeasures against muscle aging, and have been shown to attenuate age-related decreases in muscle mass, strength, and regenerative capacity, and slow or prevent impairments in muscle metabolism. We posit that exercise and physical activity can influence many of the changes in muscle during aging, and thus should be emphasized as part of a lifestyle essential to healthy aging.

Seletal muscle aging is characterized by a Sumber of structural and functional changes that are associated with increased physical limitations and risk for disease. The progressive loss of muscle mass and function, a condition or process referred to as sarcopenia (Rosenberg 1997; Cruz-Jentoft et al. 2010), has long been recognized as being among the most remarkable and deleterious of these changes. Studies performed in the 1980s and 1990s identified fundamentally important structural changes in the aging muscle (Lexell et al. 1983, 1986, 1988; Forsberg et al. 1991; Overend et al. 1992; Lexell 1997), as well as a diminished regenerative capacity and satellite cell potential (Snow 1977; Schultz and Lipton 1982). These adaptations are accompanied by neurological and vascular changes that likely further compromise muscle function (Gonzalez-Freire et al. 2014; Mendonca et al. 2016). Additionally, age-related alterations in muscle metabolism, including insulin sensitivity and mitochondrial capacity, have been extensively investigated (Tonkonogi et al. 2003; Amati et al. 2009; Consitt et al. 2013; Porter et al. 2015; Distefano et al. 2016). Despite the significant advances in the field of muscle aging, many questions remain, especially concerning the roles of both mass and function, along with the underlying mechanisms of sarcopenia and the bioenergetics of the aged muscle.

A challenge in the study of skeletal muscle aging is to decipher whether the deterioration of muscle function is attributed to age per se, or rather is a consequence of lifestyle and disease.

Editors: Juleen R. Zierath, Michael J. Joyner, and John A. Hawley

Additional Perspectives on The Biology of Exercise available at www.perspectivesinmedicine.org

Copyright (C) 2018 Cold Spring Harbor Laboratory Press; all rights reserved; doi: 10.1101/cshperspect.a029785

Cite this article as Cold Spring Harb Perspect Med 2018;8:a029785 
As proposed by Busse (1969), a combination of primary and secondary aging occurs (Busse 1969). Primary aging corresponds to the inevitable changes in cellular structure and function that happens independent of lifestyle, environmental influences, or disease. Changes involving interactions of primary aging with environmental influences and disease define secondary aging. While considerable efforts have been made to identify potential interventions that prevent or diminish primary aging, physical activity and exercise are feasible and well-established countermeasures against secondary aging (Booth et al. 2011). Exercise improves cardiorespiratory fitness in older men and women (Pruchnic et al. 2004) and decreases the likelihood of several deadly chronic diseases (Kyu et al. 2016). Exercise also increases myofiber size (Bamman et al. 2003), whole muscle mass (Harridge et al. 1999), muscle quality (Da Boit et al. 2016), improves functional abilities (Da Boit et al. 2016), and attenuates age-related decreases in muscle strength (Goodpaster et al. 2008) and increases in fat infiltration (Goodpaster et al. 2008). Furthermore, exercise can prevent age-associated muscle insulin resistance (Amati et al. 2009) and diminished mitochondrial capacity (Safdar et al. 2010).

The purpose of this review is to (1) describe the effect of aging on several skeletal muscle characteristics, (2) discuss the influence of primary and secondary aging on these processes, and (3) examine the preventive and therapeutic effects of physical activity and exercise on skeletal muscle aging. We will focus on the effects of aging on muscle morphology, mass, strength, insulin sensitivity, mitochondrial capacity, and regenerative potential. Additionally, we will discuss the beneficial effects of an active lifestyle to prevent or counteract age-related muscular changes.

\section{SKELETAL MUSCLE CHANGES WITH CHRONOLOGICAL AGING AND THE INFLUENCE OF LIFESTYLE}

Skeletal muscle has a remarkable capacity to adapt to the demands imposed on it, a process known as muscle plasticity. While chronological aging can promote changes in muscle, an im- balance between energy intake and energy expenditure have been shown to exacerbate these changes. In the following sections, we discuss the robust influence of obesity and physical activity on the age-related muscle changes. The distinct and combined effects of primary aging, obesity, and reduced physical activity on skeletal muscle, although not completely understood, are presented in Table 1. While aging is associated with decreases in muscle mass, strength, and regenerative capacity, its effect on insulin sensitivity and mitochondrial capacity is highly influenced by obesity and physical activity. Increased body fat likely potentiates the loss of muscle mass and strength, and is associated with insulin sensitivity, mitochondrial dysfunction, and impaired regenerative capacity. Conversely, physical activity can improve all of these muscle characteristics (Fig. 1). While resistance exercise is generally used to increase muscle mass and strength, and aerobic exercise is known to improve insulin sensitivity and mitochondrial capacity, additional studies are needed to better understand the optimal type and amount of physical activity required to improve muscle health.

\section{Muscle Mass, Structure, and Strength}

A decline in skeletal muscle mass (atrophy) begins during the third or fourth decade of life, and approximately $10 \%$ of muscle can be lost by the age of 50 years (Lexell et al. 1988). The rate

Table 1. Skeletal muscle characteristics and how they are affected by aging, obesity, and physical activity

\begin{tabular}{lccc}
\hline Muscle characteristic & Aging & Obesity & $\begin{array}{c}\text { Physical } \\
\text { activity }\end{array}$ \\
\hline Muscle mass & $\downarrow$ & $\downarrow$ & $\uparrow$ \\
Muscle strength & $\downarrow$ & $\downarrow$ & $\uparrow$ \\
Insulin sensitivity & $\leftrightarrow$ & $\downarrow$ & $\uparrow$ \\
Mitochondrial capacity & & & \\
$\quad$ Content & $\leftrightarrow \downarrow$ & $\downarrow$ & $\uparrow$ \\
$\quad$ Function & $\leftrightarrow \downarrow$ & $\downarrow$ & $\uparrow$ \\
$\quad$ Turnover & $?$ & $?$ & $?$ \\
Regenerative capacity & $\downarrow$ & $\downarrow$ & $\uparrow$ \\
\hline
\end{tabular}

$\downarrow$ Decrease, $\uparrow$ increase, $\leftrightarrow$ no change, $\leftrightarrow \downarrow$ no change or small effect, ? not well established. 


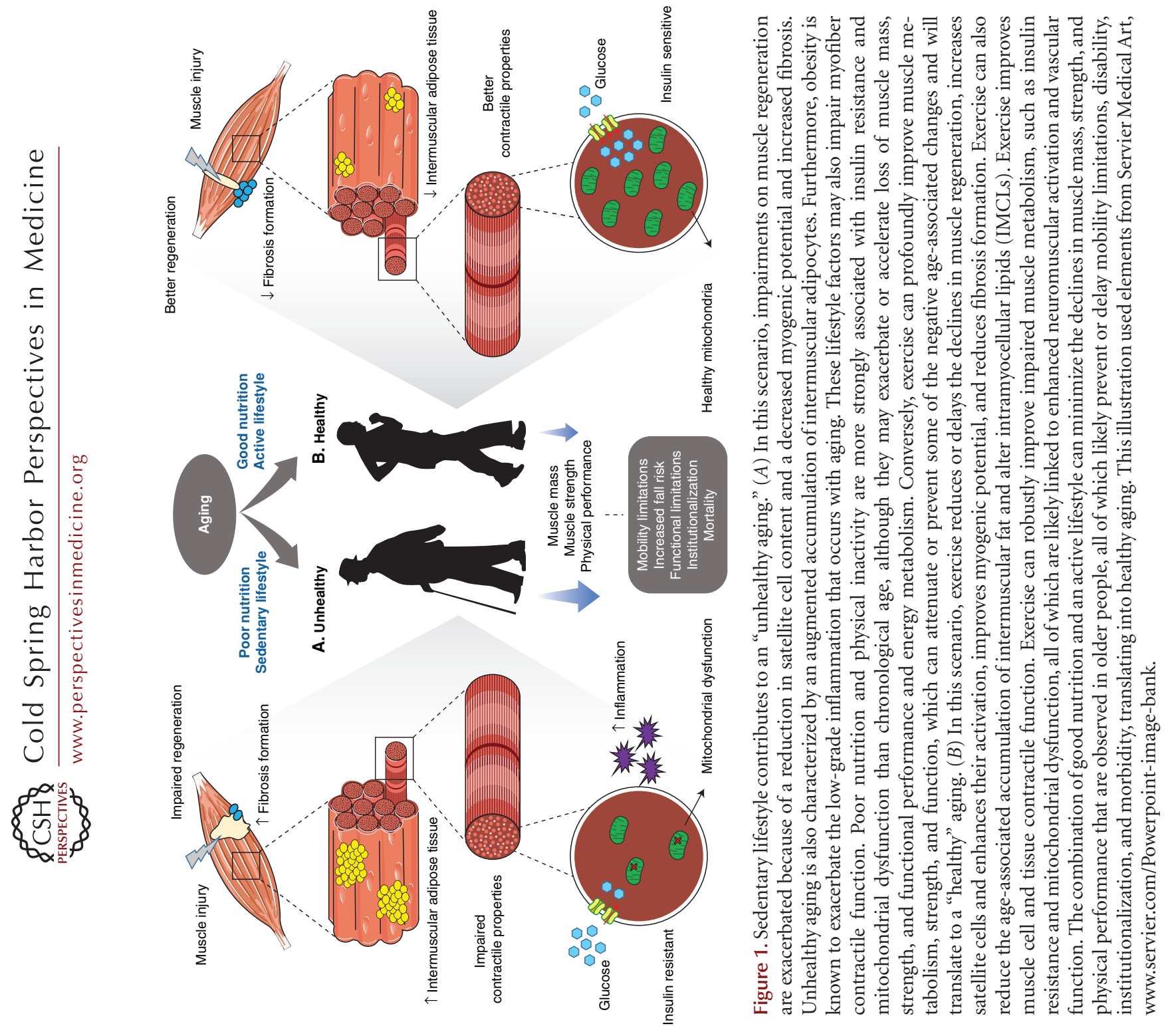


of muscle loss then accelerates so that by the seventh and eighth decades of life about $0.7 \%-0.8 \%$ of lower limb muscles is reduced per year in both men and women (Koster et al. 2011). The reduction in whole muscle mass is mainly explained by the reduced number of myofibers, and to a lesser degree by a decrease in myofiber area (Lexell et al. 1988). During muscle atrophy, signaling pathways that regulate muscle size are altered. Among the potential factors underlying the age-related muscle atrophy, decreased mitochondrial capacity and increased oxidative stress (Fulle et al. 2004; Marzetti et al. 2013), impaired satellite cell function (Alway et al. 2014), as well as increased inflammation (Schaap et al. 2009) have received considerable attention. The specific mechanisms involved in the age-related loss of muscle mass are the scope of several contemporary investigations (Peake et al. 2010; Bonaldo and Sandri 2013; Sandri et al. 2013; Rudrappa et al. 2016), yet remain incompletely understood, especially in humans.

Concomitant with muscle atrophy, muscle strength declines with aging, and together they define sarcopenia (Cruz-Jentoft et al. 2010). Muscle strength significantly decreases after 50-60 years of age (Murray et al. 1980; Lindle et al. 1997; Lynch et al. 1999). The rates of decline are approximately $2 \%-4 \%$ per year (Bassey and Harries 1993; Frontera et al. 2000a; Goodpaster et al. 2006; Delmonico et al. 2009), and are greater in lower limbs when compared to upper limbs (Landers et al. 2001; Amaral et al. 2014). Interestingly, the loss of muscle strength is about three times greater than the rates of muscle atrophy (Goodpaster et al. 2006; Koster et al. 2011). Therefore, the specific strength (i.e., strength per unit of muscle) significantly decreases with aging, suggesting a decline in muscle quality (Goodpaster et al. 2006; Koster et al. 2011). The processes responsible for the loss of muscle strength have not been elucidated. Some studies have shown an age-related deterioration in single fiber contractile function (Larsson et al. 1997; Frontera et al. 2000b). One study of young and old subjects matched for physical activity levels, however, did not observe these impairments with aging (Trappe et al. 2003).
Interestingly, an improved single fiber contractile function was reported for oldest-old subjects (87-90 yr old) when compared to young subjects, suggesting a compensatory mechanism to the decrements in whole muscle function (Grosicki et al. 2016). Impairments of muscle strength are likely due not only to decreases in muscle lean mass, but also a combination of factors that may include a decline in voluntary neural drive (Clark and Taylor 2011), impaired neuromuscular control such as lower motoneuron firing rates (Connelly et al. 1999) and nerve conduction velocities (Metter et al. 1998), increases in noncontractile adipose tissue (Goodpaster et al. 2008), and excitation-contraction uncoupling (Payne and Delbono 2004; Delbono 2011).

The aging muscle undergoes several morphological changes, which in turn may affect muscle strength and physical performance. These muscular changes are likely linked to age-related changes in the central and peripheral nervous systems, including a gradual loss of motoneurons and degeneration of neuromuscular junctions (Gonzalez-Freire et al. 2014). With aging, denervation of fibers belonging to a single motor unit (usually fast) occurs (Lexell et al. 1983). This denervation is followed by immediate reinnervation by the remaining motoneurons (usually slow). The reinnervation of muscle fibers by a different type of motoneuron results in fiber type conversion and fiber type grouping (Lexell et al. 1986). With advancing aging, motoneurons lose their regenerative capacity and some muscle fibers remain denervated resulting in their ultimate death. Atrophy of type II myofibers (Lexell et al. 1988; Lexell and Taylor 1991; Joseph et al. 2012), followed by an increased accumulation of noncontractile components, including adipose and connective tissues, is also observed (Alnaqeeb et al. 1984; Kent-Braun et al. 2000). Furthermore, older subjects have impairments in the vascular system, including a compromised central arterial compliance (Tanaka et al. 2000), endothelial wall function (Groen et al. 2014), and a reduced muscle capillary density (Groen et al. 2014). These vascular changes have the potential to further compromise skeletal muscle function by affecting the delivery of 
oxygen, hormones, growth factors, nutrients, and amino acids.

No interventions likely completely prevent the age-associated loss of muscle mass and strength. However, secondary modifiable factors have shown to play a key role in modulating these changes. In this context, sarcopenia can present with increased body fat (obesity), a condition known as sarcopenic obesity. The increased adiposity in older subjects negatively impacts muscle function independent of the loss of muscle mass (Koster et al. 2011). Longterm exposure to obesity has also been related with poor handgrip strength later in life (Stenholm et al. 2008). In addition, obesity-related conditions such as inflammatory and endocrine diseases, including type 2 diabetes, can potentiate the declines in muscle mass and strength (Park et al. 2007). Chronic low-grade inflammation is generally observed with aging, can be amplified by obesity (Schrager et al. 2007), and is associated with the age-related decreases in muscle mass and strength (Schaap et al. 2009). The mechanisms by which inflammation contributes to sarcopenia are not completely understood (Peake et al. 2010).

Physical inactivity is a key secondary factor affecting muscle aging. Physical inactivity induced by controlled bed rest induces several harmful muscular adaptations, including reductions in muscle volume and power, that are more severe in older than younger subjects (Pisot et al. 2016). These impairments were not completely restored in older individuals after a 14-day recovery period that included nutritional support and exercise (Pisot et al. 2016). Conversely, an active lifestyle has been reported to attenuate sarcopenia and prevent body fat accumulation and inflammation (Safdar et al. 2010). Resistance exercise promotes muscle hypertrophy and improves strength and physical performance. This includes significant improvements or prevention of declines in myofiber (Bamman et al. 2003) and whole muscle (Harridge et al. 1999) size, strength (Tracy et al. 1999; Bamman et al. 2003), muscle quality (Da Boit et al. 2016), and physical performance (Fiatarone et al. 1990; Da Boit et al. 2016). The underlying mechanisms for exercise-induced improve- ments in muscle function have not been elucidated. Resistance exercise acutely increases muscle protein synthesis out to $72 \mathrm{~h}$ (Miller et al. 2005), and although older subjects have a reduced rate of muscle protein synthesis compared to younger individuals, their proportional response to exercise is similar (Schulte and Yarasheski 2001). Exercise can also prevent the age-associated intermuscular adipose tissue infiltration (Goodpaster et al. 2008) and improve neural and vascular function of older subjects (Nishimune et al. 2014; Messi et al. 2016; Verdijk et al. 2016).

The degree of improvements in muscle mass and strength in response to resistance exercise have shown to vary according to the subject age (Trappe et al. 2001; Raue et al. 2009). While similar increases in muscle mass were observed in young and 74-yr-old women after resistance exercise (Trappe et al. 2001), no improvements in muscle mass was observed in octogenarian women after training (Raue et al. 2009). However, other reports of improvements in muscle mass and strength observed after resistance exercise in very old individuals $(>85 \mathrm{yr}$ old) suggests that skeletal muscle may partially retains the capacity to adapt to the mechanical load (Fiatarone et al. 1990; Harridge et al. 1999). Improvements in single muscle fiber contractile properties have also been observed in older individuals after both aerobic (Harber et al. 2009) and resistance (Trappe et al. 2000) exercise training, but these improvements have shown to be diminished in very older subjects (Slivka et al. 2008; Raue et al. 2009). Despite the generally consistent response of muscle to exercise, the degree of response varies considerably. While some studies have reported similar improvements among sexes (Tracy et al. 1999; Leenders et al. 2013), others have reported greater absolute and relative exercise-related improvements in muscle mass and strength in men than in women (Ivey et al. 2000; Bamman et al. 2003; Da Boit et al. 2016). Although specific mechanisms have been proposed to explain the diminished response to exercise in aging (Mera et al. 2016), there are likely multiple factors at play, which deserve more thorough systematic investigation. 
G. Distefano and B.H. Goodpaster

\section{Muscle Metabolism}

\section{Insulin Sensitivity}

In addition to their essential role on mobility and physical performance, skeletal muscles play a crucial role in whole-body metabolism. They modulate blood glucose levels by insulin-mediated glucose uptake, and when this is impaired, insulin resistance can lead to type 2 diabetes. While there is a higher prevalence of type 2 diabetes in older adults (Wild et al. 2004), the effects of aging on insulin resistance are less clear. A number of studies have reported a decline in insulin sensitivity with aging (Rowe et al. 1983; Fink et al. 1986). The causes of insulin resistance are complex and not fully understood. Among the factors that have shown to play a role are impaired mitochondrial function (Petersen et al. 2003), increased oxidative stress (Anderson et al. 2009), increased inflammation (Shoelson et al. 2006), and lipotoxicity (Amati 2012). This of course raises questions about the primary versus secondary effects of aging on insulin resistance. Indeed, studies indicate that increasing age per se is not a major determinant of insulin sensitivity (Lalia et al. 2016), but rather obesity, body fat distribution, and physical inactivity much more profoundly influence insulin sensitivity (Lanza et al. 2008; Amati et al. 2009, 2012; Karakelides et al. 2010). Both young and older obese subjects have lower insulin sensitivity when compared with lean individuals, independent of age (Karakelides et al. 2010). Additionally, no difference in insulin sensitivity is observed between highly trained young and adults (Lanza et al. 2008). These findings support the concept that changes in insulin sensitivity with chronological aging are likely secondary to changes in body fat and physical activity. In support of this, the variation in body fat distribution among older subjects is associated with their inflammatory profile (Koster et al. 2010). Additionally, although high levels of intramyocellular lipid (IMCL) content are observed in both athletes and in insulin resistance subjects with type 2 diabetes (Goodpaster et al. 2001), specific lipids in muscle (i.e., diacylglycerols and ceramides), likely play a significant role in the development of insulin resistance (Amati et al. 2011).

Chronic exercise in older men and women maintains high insulin sensitivity (Amati et al. 2009; Amati et al. 2012) similar to that of young endurance-trained athletes (Dube et al. 2016). Together, these findings strongly support the idea that age per se is not the cause of skeletal muscle metabolic impairments, and that chronic exercise is a primary determinant of insulin sensitivity. Indeed, one bout of exercise is sufficient to induce acute improvements in muscle glucose uptake and insulin sensitivity (Heath et al. 1983). These improvements are still present up to 1-2 days after the bout of exercise (Mikines et al. 1988; Cartee et al. 1989; Nagasawa et al. 1991). Importantly, the capacity of exercise to improve insulin sensitivity and glucose uptake is maintained at old age (Dube et al. 2008; Bienso et al. 2015). Additionally, a 5-year longitudinal study performed in older subjects (70-79 yr old) showed that maintaining modest physical activity through walking diminished the odds of developing or worsening metabolic syndrome, including insulin sensitivity (Peterson et al. 2010). Although the specific mechanisms by which exercise improves insulin sensitivity are not fully understood, it is clear that many of the myocellular factors implicated in aging and insulin resistance are also affected by exercise.

\section{Mitochondrial Capacity}

Mitochondria are essential organelles for proper cellular function and play a key role in skeletal muscle bioenergetics. The effect of aging on skeletal muscle mitochondria has been extensively investigated for several decades, but the results are contradictory. A substantial number of animal and human studies have reported decreases in mitochondrial content with chronological aging, expressed by a reduced number, density, or size of mitochondria (Orlander et al. 1978; Conley et al. 2000; Crane et al. 2010), and decreased mitochondrial DNA and protein expression (Rooyackers et al. 1996; Short et al. 2005; Lanza et al. 2008). Functional declines have also been reported including reductions 
in ATP production (Drew et al. 2003; Short et al. 2005; Mansouri et al. 2006; Lanza et al. 2008), mitochondrial respiration (Trounce et al. 1989; Kerner et al. 2001; Tonkonogi et al. 2003; Kumaran et al. 2005), mitochondrial enzymatic activities (Trounce et al. 1989; Boffoli et al. 1994; Proctor et al. 1995; Rooyackers et al. 1996; Houmard et al. 1998; Tonkonogi et al. 2003; Lanza et al. 2008; Crane et al. 2010), and increased reactive oxygen species (ROS) production (Mansouri et al. 2006; Chabi et al. 2008). Additionally, in vivo human studies have shown reduced maximal ATP flux with aging in the gastrocnemius (McCully et al. 1993), vastus lateralis (Conley et al. 2000; Larsen et al. 2012), and soleus (Petersen et al. 2003) muscles.

Despite a number of studies describing agerelated changes in mitochondrial capacity, several animal and human studies have reported no age-related trends related to mitochondrial content (Rasmussen et al. 2003; Gouspillou et al. 2014), enzymatic activity (Brierley et al. 1996; Chabi et al. 2008), ATP synthesis (Barrientos et al. 1996; Rasmussen et al. 2003), mitochondrial respiration (Barrientos et al. 1996; Kerner et al. 2001; Hutter et al. 2007; Chabi et al. 2008; Gouspillou et al. 2014; Distefano et al. 2016), activity of electron transport chain complexes (Barrientos et al. 1996; Brierley et al. 1996; Rasmussen et al. 2003), and ROS production (Drew et al. 2003; Tonkonogi et al. 2003; Gouspillou et al. 2014). Furthermore, in vivo studies have failed to show changes in maximal ATP flux with aging (Chretien et al. 1998; Kent-Braun and Ng 2000; Lanza et al. 2005, 2007).

In addition to mitochondrial content and function, recent studies have highlighted the importance of mitochondrial morphology and turnover for proper mitochondrial function (Detmer and Chan 2007), Briefly, mitochondria integrity relies on the efficiency of quality control processes, and their morphology are regulated by continuous fusion, fission, and mitophagy (Ono et al. 2001; Twig et al. 2008a,b). Limited animal and human studies to date have examined mitochondrial quality control processes in muscle aging, but the results are inconsistent and need to be further investigated. While some have found no age-related trends in mitochondrial fusion and fission (Bori et al 2012; Konopka et al. 2014), others have described both an increased fission (Iqbal et al. 2013), or increased fusion (Leduc-Gaudet et al. 2015) in older muscles.

The contradictory associations between aging and mitochondria could be because of differences in study methodology. Several diverse measures can be used to assess mitochondrial content and function (Lanza and Nair 2010; Hepple 2014), and it is possible that aging does not affect all mitochondrial characteristics equally. Additionally, studies performed in isolated mitochondria, a method that does not preserve the complex structural arrangement of mitochondria, have been reported to exaggerate functional age-related impairments when compared to permeabilized myofibers (Picard et al. 2010). In addition to study methodology, factors associated with secondary aging such as body fat and physical activity levels influence skeletal muscle mitochondrial capacity and the expression of mitochondrial fission and fusion proteins (Hutter et al. 2007; Distefano et al. 2016). Obese subjects have displayed reduced capacity for lipid oxidation, and lowered activity of mitochondrial enzymes (Kim et al. 2000; Thyfault et al. 2004). Similarly, decreased physical activity can adversely affect mitochondrial capacity (Booth and Holloszy 1977; Ringholm et al. 2011).

The ability of exercise to increase mitochondrial content and function is well documented (Holloszy et al. 1970; Dohm et al. 1973). Exercise training, including endurance and resistance exercise, stimulates mitochondrial biogenesis through increases in the peroxisome proliferator-activated receptor $\gamma$ coactivator $1 \alpha$ (PGC-1 $\alpha$ ) (Baar et al. 2002; Geng et al. 2010). Furthermore, recent studies have suggested that exercise can improve function/efficiency of mitochondria through remodeling of the mitochondrial network (fusion, fission, and autophagy) (Cartoni et al. 2005; Ding et al. 2010; Perry et al. 2010; Smuder et al. 2011). Several studies have shown that mitochondrial function is not affected by chronological aging, but rather by decreases in physical activity that normally occurs with aging (Barrientos et al. 
1996; Brierley et al. 1996). No differences in mitochondrial content and respiration was observed between young and old subjects matched for physical activity, both engaged in moderateto vigorous-intensity exercise training (Gouspillou et al. 2014). Studies that included a group of older trained subjects have been performed in an attempt to investigate whether maintenance of physical activity levels during aging can prevent decreases in mitochondrial capacity. Mitochondrial content, biogenesis, electron transfer chain function, and antioxidant capacity is preserved in skeletal muscle of active older individuals (Safdar et al. 2010). Similarly, muscle biopsies from well-trained seniors who exercised regularly in the previous 30 years showed that lifelong physical exercise delays age-associated skeletal muscle declines (Zampieri et al. 2014). These well-trained seniors presented better mitochondria organization, including preserved fiber morphology and ultrastructure of intracellular organelles involved in calcium handling and ATP production, and lowered expression of genes related to autophagy and ROS in comparison with health-matched sedentary seniors. Likewise, age-related declines in oxidative capacity (Proctor et al. 1995), mitochondrial ATP production (Lanza et al. 2008), and citrate synthase activity (Lanza et al. 2008) have been observed in sedentary subjects, but not in endurance-trained subjects.

Recent evidence has also suggested that mitochondria may play a key role in sarcopenia. An imbalance between mitochondrial fusion and fission and an impaired mitochondrial turnover resulting from insufficient biogenesis and/or defective autophagic removal of dysfunctional mitochondria are all factors that may be involved in the loss of muscle mass during aging. Specifically, mitochondrial dysfunction and increased ROS production stimulates catabolic signaling pathways and muscle atrophy by activating the two major proteolytic systems: the ubiquitin proteasome and the autophagy lysosome (Sandri et al. 2004; Tong et al. 2009). Several in vitro and animal studies have provided information on the molecular pathways involved in these processes (Sandri et al. 2004; Mammucari et al. 2007; Masiero et al. 2009;
Romanello et al. 2010), but the exact role of these processes in regulating muscle mass still remains poorly understood in humans. Recent evidence has also shown that lower mitochondrial capacity and efficiency is associated with reduced physical performance in older adults (Coen et al. 2013). Similarly, high-functioning elderly individuals have been shown to maintain muscle mass and mitochondrial capacity, whereas low-functioning elderly individuals show decreased muscle mass and mitochondrial function in comparison to young individuals (Joseph et al. 2012). These results suggest a potential role for mitochondria in sarcopenia and physical function in aging.

\section{Muscle Regenerative Capacity}

Skeletal muscle has an amazing capacity for regeneration that relies on resident stem cells, also identified as satellite cells. In response to muscle injury or stress, quiescent satellite cells are activated, proliferate, and differentiate into a myogenic lineage to endure regeneration or muscle growth (Yin et al. 2013). Some activated satellite cells self-renew and return to quiescence to maintain the satellite cell pool (Yin et al. 2013). Impairments in any phase of the satellite cell cycle may result in a deficient muscle regeneration that can lead to detriments in muscle contractile function. Aged skeletal muscle has previously been shown to possess a diminished (Joanisse et al. 2016) or delayed regeneration (Shavlakadze et al. 2010), and an increased potential for fibrosis formation after injury (Brack et al. 2007). A reduced number and impaired function of satellite cells is also observed (Brack et al. 2005; Chakkalakal et al. 2012; Sousa-Victor et al. 2014). Additionally, aged muscle has attenuated regrowth following atrophy-inducing events when compared to younger muscles (Pisot et al. 2016), but the specific mechanisms responsible for the loss of growth capacity are unknown. Due to their essential role in muscle regeneration and growth, several studies have investigated whether an impaired satellite cell potential would lead to sarcopenia. Although some have supported this hypothesis (Verdijk et al. 2007), strong re- 
cent evidence has failed to support these associations (Fry et al. 2015).

Recent discoveries have revealed potential molecular and cellular mechanisms responsible for the age-related impairments in muscle regeneration. Satellite cell optimal function relies on the appropriate support from the systemic environment (circulation), local microenvironment (niche), as well as their intrinsic capacity (Conboy et al. 2005; Yin et al. 2013; Sousa-Victor et al. 2014). Heterochronic parabiosis studies, in which young and old animals join the same circulatory system, highlight the influence of the systemic environment on satellite cell function demonstrating an improved regenerative capacity of old satellite cells when exposed to a young environment (Conboy et al. 2005). Proper stem cell function has also been shown to depend on growth factors, trophic factors, and cytokines from the surrounding myofiber microenvironment (Jasper and Kennedy 2012). Recently, it has been shown that, in addition to extrinsic factors, intrinsic satellite cell changes are also responsible for the age-related defective regenerative capacity (Sousa-Victor et al. 2014). These alterations were present in satellite cells from very old animals, and were not rejuvenated by a youthful environment (Sousa-Victor et al. 2014).

In addition to chronological aging, other secondary factors have been shown to influence muscle regenerative capacity. An impaired muscle regeneration after injury is observed in obese mice when compared to normal weight controls (Nguyen et al. 2011; Fu et al. 2016), including a decreased expression of myogenic genes, number of newly formed regenerated fibers, and satellite cell pool (Fu et al. 2016). The increased inflammation that occurs with obesity has also been shown to contribute to these impairments (Brown et al. 2015). Physical activity has been shown to positively affect the regenerative capacity of older muscles. Both resistance and endurance exercise training ranging from few weeks to months have shown to increase the number of satellite cells in old animals and subjects (Roth et al. 2001; Verdijk et al. 2009; Leenders et al. 2013; Joanisse et al. 2016). Importantly, lifelong endurance runners have been shown to possess a similar density of satellite cells in type I and II myofibers despite a decrease in myofiber distribution and cross-sectional area (Mackey et al. 2014). Additionally, improved muscle regeneration in trained mice has been observed with a concomitant improvement in vascularization and inflammatory response (Joanisse et al. 2016).

\section{CONCLUDING REMARKS AND FUTURE PERSPECTIVES}

The isolated impact of aging on skeletal muscle is difficult to disentangle from the many other factors that change concurrently with aging, including decreased moderate- to vigorous-intensity physical activity and increased sedentary behavior, as well as augmented adiposity. On one hand, no single intervention can completely prevent the age-related loss of muscle mass, strength, and regenerative capacity. On the other, exercise and physical activity can significantly attenuate, or in some cases prevent, these declines in muscle metabolism and function. Skeletal muscle partially retains its plasticity in response to exercise with aging, providing compelling evidence that many of the negative age-associated changes in muscle function and metabolism are caused by lifestyle changes secondary to aging, most notably physical inactivity. The fields of muscle aging and exercise physiology have synergized to provide important insights into primary effects of aging on muscle, and which age-associated changes can be attenuated or prevented by exercise. We need to better understand, however, which specific responses to exercise differ in older subjects, the underlying mechanism by which aging may affect acute and chronic exercise responses, and the variation in the individual response to exercise. Moreover, the field of muscle aging needs to link the myocellular responses to exercise to many of its health benefits.

\section{REFERENCES}

Alnaqeeb MA, Al Zaid NS, Goldspink G. 1984. Connective tissue changes and physical properties of developing and ageing skeletal muscle. J Anat 139: 677-689. 
Alway SE, Myers MJ, Mohamed JS. 2014. Regulation of satellite cell function in sarcopenia. Front Aging Neurosci 6: 246.

Amaral JF, Alvim FC, Castro EA, Doimo LA, Silva MV, Novo Junior JM. 2014. Influence of aging on isometric muscle strength, fat-free mass and electromyographic signal power of the upper and lower limbs in women. Braz J Phys Ther 18: 183-190.

Amati F. 2012. Revisiting the diacylglycerol-induced insulin resistance hypothesis. Obes Rev 13: 40-50.

Amati F, Dube JJ, Coen PM, Stefanovic-Racic M, Toledo FG, Goodpaster BH. 2009. Physical inactivity and obesity underlie the insulin resistance of aging. Diabetes Care 32: 1547-1549.

Amati F, Dube JJ, Alvarez-Carnero E, Edreira MM, Chomentowski P, Coen PM, Switzer GE, Bickel PE, Stefanovic-Racic M, Toledo FG, et al. 2011. Skeletal muscle triglycerides, diacylglycerols, and ceramides in insulin resistance: Another paradox in endurance-trained athletes? Diabetes 60: 2588-2597.

Amati F, Pennant M, Azuma K, Dube JJ, Toledo FG, Ross AP, Kelley DE, Goodpaster BH. 2012. Lower thigh subcutaneous and higher visceral abdominal adipose tissue content both contribute to insulin resistance. Obesity 20: 1115-1117.

Anderson EJ, Lustig ME, Boyle KE, Woodlief TL, Kane DA, Lin CT, Price JWIII, Kang L, Rabinovitch PS, Szeto HH, et al. 2009. Mitochondrial $\mathrm{H} 2 \mathrm{O} 2$ emission and cellular redox state link excess fat intake to insulin resistance in both rodents and humans. J Clin Invest 119: 573-581.

Baar K, Wende AR, Jones TE, Marison M, Nolte LA, Chen M, Kelly DP, Holloszy JO. 2002. Adaptations of skeletal muscle to exercise: Rapid increase in the transcriptional coactivator PGC-1. FASEB J 16: 1879-1886.

Bamman MM, Hill VJ, Adams GR, Haddad F, Wetzstein CJ, Gower BA, Ahmed A, Hunter GR. 2003. Gender differences in resistance-training-induced myofiber hypertrophy among older adults. J Gerontol A Biol Sci Med Sci 58: $108-116$.

Barrientos A, Casademont J, Rotig A, Miro O, Urbano-Marquez A, Rustin P, Cardellach F. 1996. Absence of relationship between the level of electron transport chain activities and aging in human skeletal muscle. Biochem Biophys Res Commun 229: 536-539.

Bassey EJ, Harries UJ. 1993. Normal values for handgrip strength in 920 men and women aged over 65 years, and longitudinal changes over 4 years in 620 survivors. Clin Sci (Lond) 84: 331-337.

Bienso RS, Olesen J, Gliemann L, Schmidt JF, Matzen MS, Wojtaszewski JF, Hellsten Y, Pilegaard H. 2015. Effects of exercise training on regulation of skeletal muscle glucose metabolism in elderly men. J Gerontol A Biol Sci Med Sci 70: $866-872$.

Boffoli D, Scacco SC, Vergari R, Solarino G, Santacroce G, Papa S. 1994. Decline with age of the respiratory chain activity in human skeletal muscle. Biochim Biophys Acta 1226: $73-82$.

Bonaldo P, Sandri M. 2013. Cellular and molecular mechanisms of muscle atrophy. Dis Model Mech 6: 25-39.

Booth FW, Holloszy JO. 1977. Cytochrome c turnover in rat skeletal muscles. J Biol Chem 252: 416-419.
Booth FW, Laye MJ, Roberts MD. 2011. Lifetime sedentary living accelerates some aspects of secondary aging. J Appl Physiol (1985) 111: 1497-1504.

Bori Z, Zhao Z, Koltai E, Fatouros IG, Jamurtas AZ, Douroudos II, Terzis G, Chatzinikolaou A, Sovatzidis A, Draganidis D, et al. 2012. The effects of aging, physical training, and a single bout of exercise on mitochondrial protein expression in human skeletal muscle. Exp Gerontol 47: 417-424.

Brack AS, Bildsoe H, Hughes SM. 2005. Evidence that satellite cell decrement contributes to preferential decline in nuclear number from large fibres during murine agerelated muscle atrophy. J Cell Sci 118: 4813-4821.

Brack AS, Conboy MJ, Roy S, Lee M, Kuo CJ, Keller C, Rando TA. 2007. Increased Wnt signaling during aging alters muscle stem cell fate and increases fibrosis. Science 317: 807-810.

Brierley EJ, Johnson MA, James OF, Turnbull DM. 1996. Effects of physical activity and age on mitochondrial function. QJM 89: 251-258.

Brown LA, Lee DE, Patton JF, Perry RAJr, Brown JL, Baum JI, Smith-Blair N, Greene NP, Washington TA. 2015. Dietinduced obesity alters anabolic signalling in mice at the onset of skeletal muscle regeneration. Acta Physiol 215: 46-57.

Busse EW. 1969. Theories of aging. In Behavior and adaptation in late life (ed. Busse EW, Pfeiffer E). Little, Brown, Boston, MA.

Cartee GD, Young DA, Sleeper MD, Zierath J, WallbergHenriksson H, Holloszy JO. 1989. Prolonged increase in insulin-stimulated glucose transport in muscle after exercise. Am J Physiol 256: E494-E499.

Cartoni R, Leger B, Hock MB, Praz M, Crettenand A, Pich S, Ziltener JL, Luthi F, Deriaz O, Zorzano A, et al. 2005 Mitofusins $1 / 2$ and ERR $\alpha$ expression are increased in human skeletal muscle after physical exercise. J Physiol 567: $349-358$.

Chabi B, Ljubicic V, Menzies KJ, Huang JH, Saleem A, Hood DA. 2008. Mitochondrial function and apoptotic susceptibility in aging skeletal muscle. Aging Cell 7: 2-12.

Chakkalakal JV, Jones KM, Basson MA, Brack AS. 2012. The aged niche disrupts muscle stem cell quiescence. Nature 490: $355-360$.

Chretien D, Gallego J, Barrientos A, Casademont J, Cardellach F, Munnich A, Rotig A, Rustin P. 1998. Biochemical parameters for the diagnosis of mitochondrial respiratory chain deficiency in humans, and their lack of agerelated changes. Biochem J 329: 249-254.

Clark BC, Taylor JL. 2011. Age-related changes in motor cortical properties and voluntary activation of skeletal muscle. Curr Aging Sci 4: 192-199.

Coen PM, Jubrias SA, Distefano G, Amati F, Mackey DC, Glynn NW, Manini TM, Wohlgemuth SE, Leeuwenburgh C, Cummings SR, et al. 2013. Skeletal muscle mitochondrial energetics are associated with maximal aerobic capacity and walking speed in older adults. J Gerontol A Biol Sci Med Sci 68: 447-455.

Conboy IM, Conboy MJ, Wagers AJ, Girma ER, Weissman IL, Rando TA. 2005. Rejuvenation of aged progenitor cells by exposure to a young systemic environment. Nature 433: $760-764$ 
Conley KE, Jubrias SA, Esselman PC. 2000. Oxidative capacity and ageing in human muscle. J Physiol 526: $203-$ 210.

Connelly DM, Rice CL, Roos MR, Vandervoort AA. 1999. Motor unit firing rates and contractile properties in tibialis anterior of young and old men. J Appl Physiol (1985) 87: 843-852.

Consitt LA, Van Meter J, Newton CA, Collier DN, Dar MS, Wojtaszewski JF, Treebak JT, Tanner CJ, Houmard JA. 2013. Impairments in site-specific AS160 phosphorylation and effects of exercise training. Diabetes 62: $3437-$ 3447.

Crane JD, Devries MC, Safdar A, Hamadeh MJ, Tarnopolsky MA. 2010. The effect of aging on human skeletal muscle mitochondrial and intramyocellular lipid ultrastructure. J Gerontol A Biol Sci Med Sci 65: 119-128.

Cruz-Jentoft AJ, Baeyens JP, Bauer JM, Boirie Y, Cederholm T, Landi F, Martin FC, Michel JP, Rolland Y, Schneider SM, et al. 2010. Sarcopenia: European consensus on definition and diagnosis: Report of the European Working Group on Sarcopenia in Older People. Age Ageing 39: 412-423.

Da Boit M, Sibson R, Meakin JR, Aspden RM, Thies F Mangoni AA, Gray SR. 2016. Sex differences in the response to resistance exercise training in older people. Physiol Rep 4: e12834.

Delbono O. 2011. Expression and regulation of excitationcontraction coupling proteins in aging skeletal muscle. Curr Aging Sci 4: 248-259.

Delmonico MJ, Harris TB, Visser M, Park SW, Conroy MB, Velasquez-Mieyer P, Boudreau R, Manini TM, Nevitt M, Newman AB, et al. 2009. Longitudinal study of muscle strength, quality, and adipose tissue infiltration. Am J Clin Nutr 90: 1579-1585.

Detmer SA, Chan DC. 2007. Functions and dysfunctions of mitochondrial dynamics. Nat Rev Mol Cell Biol 8: 870879.

Ding H, Jiang N, Liu H, Liu X, Liu D, Zhao F, Wen L, Liu S, Ji LL, Zhang Y. 2010. Response of mitochondrial fusion and fission protein gene expression to exercise in rat skeletal muscle. Biochim Biophys Acta 1800: 250-256.

Distefano G, Standley RA, Dube JJ, Carnero EA, Ritov VB, Stefanovic-Racic M, Toledo FG, Piva SR, Goodpaster BH, Coen PM. 2016. Chronological age does not influence ex-vivo mitochondrial respiration and quality control in skeletal muscle. J Gerontol A Biol Sci Med Sci doi: 10.1093/gerona/glw102.

Dohm GL, Huston RL, Askew EW, Fleshood HL. 1973. Effects of exercise, training, and diet on muscle citric acid cycle enzyme activity. Can J Biochem 51: 849-854.

Drew B, Phaneuf S, Dirks A, Selman C, Gredilla R, Lezza A, Barja G, Leeuwenburgh C. 2003. Effects of aging and caloric restriction on mitochondrial energy production in gastrocnemius muscle and heart. Am J Physiol Regul Integr Comp Physiol 284: R474-R480.

Dube JJ, Amati F, Stefanovic-Racic M, Toledo FG, Sauers SE, Goodpaster BH. 2008. Exercise-induced alterations in intramyocellular lipids and insulin resistance: The athlete's paradox revisited. Am J Physiol Endocrinol Metab 294: E882-E888.

Dube JJ, Broskey NT, Despines AA, Stefanovic-Racic M, Toledo FG, Goodpaster BH, Amati F. 2016. Muscle char- acteristics and substrate energetics in lifelong endurance athletes. Med Sci Sports Exerc 48: 472-480.

Fiatarone MA, Marks EC, Ryan ND, Meredith CN, Lipsitz LA, Evans WJ. 1990. High-intensity strength training in nonagenarians. Effects on skeletal muscle. JAMA 263: 3029-3034.

Fink RI, Wallace P, Olefsky JM. 1986. Effects of aging on glucose-mediated glucose disposal and glucose transport. J Clin Invest 77: 2034-2041.

Forsberg AM, Nilsson E, Werneman J, Bergstrom J, Hultman E. 1991. Muscle composition in relation to age and sex. Clin Sci 81: 249-256.

Frontera WR, Hughes VA, Fielding RA, Fiatarone MA, Evans WJ, Roubenoff R. 2000a. Aging of skeletal muscle: A 12 yr longitudinal study. J Appl Physiol (1985) 88: 13211326.

Frontera WR, Suh D, Krivickas LS, Hughes VA, Goldstein R, Roubenoff R. 2000b. Skeletal muscle fiber quality in older men and women. Am J Physiol Cell Physiol 279: C611C618.

Fry CS, Lee JD, Mula J, Kirby TJ, Jackson JR, Liu F, Yang L, Mendias CL, Dupont-Versteegden EE, McCarthy JJ, et al. 2015. Inducible depletion of satellite cells in adult, sedentary mice impairs muscle regenerative capacity without affecting sarcopenia. Nat Med 21: 76-80.

Fu X, Zhu M, Zhang S, Foretz M, Viollet B, Du M. 2016. Obesity impairs skeletal muscle regeneration through inhibition of AMPK. Diabetes 65: 188-200.

Fulle S, Protasi F, Di Tano G, Pietrangelo T, Beltramin A, Boncompagni S, Vecchiet L, Fano G. 2004. The contribution of reactive oxygen species to sarcopenia and muscle ageing. Exp Gerontol 39: 17-24.

Geng T, Li P, Okutsu M, Yin X, Kwek J, Zhang M, Yan Z. 2010. PGC- $1 \alpha$ plays a functional role in exercise-induced mitochondrial biogenesis and angiogenesis but not fibertype transformation in mouse skeletal muscle. Am J Physiol Cell Physiol 298: C572-C579.

Gonzalez-Freire M, de Cabo R, Studenski SA, Ferrucci L. 2014. The neuromuscular junction: Aging at the crossroad between nerves and muscle. Front Aging Neurosci 6: 208.

Goodpaster BH, He J, Watkins S, Kelley DE. 2001. Skeletal muscle lipid content and insulin resistance: Evidence for a paradox in endurance-trained athletes. J Clin Endocrinol Metab 86: 5755-5761.

Goodpaster BH, Park SW, Harris TB, Kritchevsky SB, Nevitt M, Schwartz AV, Simonsick EM, Tylavsky FA, Visser M, Newman AB. 2006. The loss of skeletal muscle strength, mass, and quality in older adults: The health, aging and body composition study. J Gerontol A Biol Sci Med Sci 61: 1059-1064.

Goodpaster BH, Chomentowski P, Ward BK, Rossi A, Glynn NW, Delmonico MJ, Kritchevsky SB, Pahor M, Newman AB. 2008. Effects of physical activity on strength and skeletal muscle fat infiltration in older adults: A randomized controlled trial. J Appl Physiol (1985) 105: 1498 1503 .

Gouspillou G, Sgarioto N, Kapchinsky S, Purves-Smith F, Norris B, Pion CH, Barbat-Artigas S, Lemieux F, Taivassalo T, Morais JA, et al. 2014. Increased sensitivity to mitochondrial permeability transition and myonuclear 
G. Distefano and B.H. Goodpaster

translocation of endonuclease $\mathrm{G}$ in atrophied muscle of physically active older humans. FASEB J 28: 1621-1633.

Groen BB, Hamer HM, Snijders T, van Kranenburg J, Frijns D, Vink H, van Loon LJ. 2014. Skeletal muscle capillary density and microvascular function are compromised with aging and type 2 diabetes. J Appl Physiol (1985) 116: $998-1005$.

Grosicki GJ, Standley R, Murach KA, Raue U, Minchev K, Coen P, Newman AB, Cummings S, Harris T, Kritchevsky S, et al. 2016. Improved single muscle fiber quality in the oldest-old. J Appl Physiol (1985) 121: 878-884.

Harber MP, Konopka AR, Douglass MD, Minchev K, Kaminsky LA, Trappe TA, Trappe S. 2009. Aerobic exercise training improves whole muscle and single myofiber size and function in older women. Am J Physiol Regul Integr Comp Physiol 297: R1452-R1459.

Harridge SD, Kryger A, Stensgaard A. 1999. Knee extensor strength, activation, and size in very elderly people following strength training. Muscle Nerve 22: 831-839.

Heath GW, Gavin JRIII, Hinderliter JM, Hagberg JM, Bloomfield SA, Holloszy JO. 1983. Effects of exercise and lack of exercise on glucose tolerance and insulin sensitivity. J Appl Physiol Respir Environ Exerc Physiol 55: 512-517.

Hepple RT. 2014. Mitochondrial involvement and impact in aging skeletal muscle. Front Aging Neurosci 6: 211.

Holloszy JO, Oscai LB, Don IJ, Mole PA. 1970. Mitochondrial citric acid cycle and related enzymes: Adaptive response to exercise. Biochem Biophys Res Commun 40: $1368-1373$.

Houmard JA, Weidner ML, Gavigan KE, Tyndall GL, Hickey MS, Alshami A. 1998. Fiber type and citrate synthase activity in the human gastrocnemius and vastus lateralis with aging. J Appl Physiol (1985) 85: 1337-1341.

Hutter E, Skovbro M, Lener B, Prats C, Rabol R, Dela F, Jansen-Durr P. 2007. Oxidative stress and mitochondrial impairment can be separated from lipofuscin accumulation in aged human skeletal muscle. Aging Cell 6: $245-$ 256.

Iqbal S, Ostojic O, Singh K, Joseph AM, Hood DA. 2013. Expression of mitochondrial fission and fusion regulatory proteins in skeletal muscle during chronic use and disuse. Muscle Nerve 48: 963-970.

Ivey FM, Roth SM, Ferrell RE, Tracy BL, Lemmer JT, Hurlbut DE, Martel GF, Siegel EL, Fozard JL, Jeffrey Metter E, et al. 2000. Effects of age, gender, and myostatin genotype on the hypertrophic response to heavy resistance strength training. J Gerontol A Biol Sci Med Sci 55: M641-M648.

Jasper H, Kennedy BK. 2012. Niche science: The aging stem cell. Cell Cycle 11: 2959-2960.

Joanisse S, Nederveen JP, Baker JM, Snijders T, Iacono C, Parise G. 2016. Exercise conditioning in old mice improves skeletal muscle regeneration. FASEB J 30: 32563268.

Joseph AM, Adhihetty PJ, Buford TW, Wohlgemuth SE, Lees HA, Nguyen LM, Aranda JM, Sandesara BD, Pahor M, Manini TM, et al. 2012. The impact of aging on mitochondrial function and biogenesis pathways in skeletal muscle of sedentary high- and low-functioning elderly individuals. Aging Cell 11: 801-809.
Karakelides H, Irving BA, Short KR, O'Brien P, Nair KS. 2010. Age, obesity, and sex effects on insulin sensitivity and skeletal muscle mitochondrial function. Diabetes 59: 89-97.

Kent-Braun JA, Ng AV. 2000. Skeletal muscle oxidative capacity in young and older women and men. J Appl Physiol (1985) 89: 1072-1078.

Kent-Braun JA, Ng AV, Young K. 2000. Skeletal muscle contractile and noncontractile components in young and older women and men. J Appl Physiol (1985) 88: 662 668.

Kerner J, Turkaly PJ, Minkler PE, Hoppel CL. 2001. Aging skeletal muscle mitochondria in the rat: Decreased uncoupling protein-3 content. Am J Physiol Endocrinol Metab 281: E1054-E1062.

Kim JY, Hickner RC, Cortright RL, Dohm GL, Houmard JA. 2000. Lipid oxidation is reduced in obese human skeletal muscle. Am J Physiol Endocrinol Metab 279: E1039E1044.

Konopka AR, Suer MK, Wolff CA, Harber MP. 2014. Markers of human skeletal muscle mitochondrial biogenesis and quality control: Effects of age and aerobic exercise training. J Gerontol A Biol Sci Med Sci 69: 371-378.

Koster A, Stenholm S, Alley DE, Kim LJ, Simonsick EM, Kanaya AM, Visser M, Houston DK, Nicklas BJ, Tylavsky FA, et al. 2010. Body fat distribution and inflammation among obese older adults with and without metabolic syndrome. Obesity 18: 2354-2361.

Koster A, Ding J, Stenholm S, Caserotti P, Houston DK, Nicklas BJ, You T, Lee JS, Visser M, Newman AB, et al. 2011. Does the amount of fat mass predict age-related loss of lean mass, muscle strength, and muscle quality in older adults? J Gerontol A Biol Sci Med Sci 66: 888-895.

Kumaran S, Panneerselvam KS, Shila S, Sivarajan K, Panneerselvam C. 2005. Age-associated deficit of mitochondrial oxidative phosphorylation in skeletal muscle: Role of carnitine and lipoic acid. Mol Cell Biochem 280: 83-89.

Kyu HH, Bachman VF, Alexander LT, Mumford JE, Afshin A, Estep K, Veerman JL, Delwiche K, Iannarone ML, Moyer ML, et al. 2016. Physical activity and risk of breast cancer, colon cancer, diabetes, ischemic heart disease, and ischemic stroke events: Systematic review and dose-response meta-analysis for the Global Burden of Disease Study 2013. BMJ 354: i3857.

Lalia AZ, Dasari S, Johnson ML, Robinson MM, Konopka AR, Distelmaier K, Port JD, Glavin MT, Esponda RR, Nair KS, et al. 2016. Predictors of whole-body insulin sensitivity across ages and adiposity in adult humans. J Clin Endocrinol Metab 101: 626-634.

Landers KA, Hunter GR, Wetzstein CJ, Bamman MM, Weinsier RL. 2001. The interrelationship among muscle mass, strength, and the ability to perform physical tasks of daily living in younger and older women. J Gerontol $A$ Biol Sci Med Sci 56: B443-B448.

Lanza IR, Nair KS. 2010. Mitochondrial metabolic function assessed in vivo and in vitro. Curr Opin Clin Nutr Metab Care 13: 511-517.

Lanza IR, Befroy DE, Kent-Braun JA. 2005. Age-related changes in ATP-producing pathways in human skeletal muscle in vivo. J Appl Physiol (1985) 99: 1736-1744.

Lanza IR, Larsen RG, Kent-Braun JA. 2007. Effects of old age on human skeletal muscle energetics during fatiguing 
contractions with and without blood flow. J Physiol 583: $1093-1105$.

Lanza IR, Short DK, Short KR, Raghavakaimal S, Basu R, Joyner MJ, McConnell JP, Nair KS. 2008. Endurance exercise as a countermeasure for aging. Diabetes 57: $2933-$ 2942.

Larsen RG, Callahan DM, Foulis SA, Kent-Braun JA. 2012. Age-related changes in oxidative capacity differ between locomotory muscles and are associated with physical activity behavior. Appl Physiol Nutr Metab 37: 88-99.

Larsson L, Li X, Frontera WR. 1997. Effects of aging on shortening velocity and myosin isoform composition in single human skeletal muscle cells. Am J Physiol 272: C638-C649.

Leduc-Gaudet JP, Picard M, St-Jean Pelletier F, Sgarioto N, Auger MJ, Vallee J, Robitaille R, St-Pierre DH, Gouspillou G. 2015. Mitochondrial morphology is altered in atrophied skeletal muscle of aged mice. Oncotarget 6: 1792317937.

Leenders M, Verdijk LB, van der Hoeven L, van Kranenburg J, Nilwik R, van Loon LJ. 2013. Elderly men and women benefit equally from prolonged resistance-type exercise training. J Gerontol A Biol Sci Med Sci 68: 769-779.

Lexell J. 1997. Evidence for nervous system degeneration with advancing age. J Nutr 127: 1011S-1013S.

Lexell J, Taylor CC. 1991. Variability in muscle fibre areas in whole human quadriceps muscle: Effects of increasing age. J Anat 174: 239-249.

Lexell J, Henriksson-Larsen K, Winblad B, Sjostrom M. 1983. Distribution of different fiber types in human skeletal muscles: Effects of aging studied in whole muscle cross sections. Muscle Nerve 6: 588-595.

Lexell J, Downham D, Sjostrom M. 1986. Distribution of different fibre types in human skeletal muscles. Fibre type arrangement in $\mathrm{m}$. vastus lateralis from three groups of healthy men between 15 and 83 years. J Neurol Sci 72: 211-222.

Lexell J, Taylor CC, Sjostrom M. 1988. What is the cause of the ageing atrophy? Total number, size and proportion of different fiber types studied in whole vastus lateralis muscle from 15- to 83-year-old men. J Neurol Sci 84: $275-$ 294.

Lindle RS, Metter EJ, Lynch NA, Fleg JL, Fozard JL, Tobin J, Roy TA, Hurley BF. 1997. Age and gender comparisons of muscle strength in 654 women and men aged $20-93 \mathrm{yr} . J$ Appl Physiol (1985) 83: 1581-1587.

Lynch NA, Metter EJ, Lindle RS, Fozard JL, Tobin JD, Roy TA, Fleg JL, Hurley BF. 1999. Muscle quality. I: Age-associated differences between arm and leg muscle groups. J Appl Physiol (1985) 86: 188-194.

Mackey AL, Karlsen A, Couppe C, Mikkelsen UR, Nielsen RH, Magnusson SP, Kjaer M. 2014. Differential satellite cell density of type I and II fibres with lifelong endurance running in old men. Acta Physiol (Oxf) 210: 612-627.

Mammucari C, Milan G, Romanello V, Masiero E, Rudolf R, Del Piccolo P, Burden SJ, Di Lisi R, Sandri C, Zhao J, et al. 2007. FoxO3 controls autophagy in skeletal muscle in vivo. Cell Metab 6: 458-471.

Mansouri A, Muller FL, Liu Y, Ng R, Faulkner J, Hamilton M, Richardson A, Huang TT, Epstein CJ, Van Remmen H. 2006. Alterations in mitochondrial function, hydrogen peroxide release and oxidative damage in mouse hindlimb skeletal muscle during aging. Mech Ageing Dev 127: 298-306.

Marzetti E, Calvani R, Cesari M, Buford TW, Lorenzi M, Behnke BJ, Leeuwenburgh C. 2013. Mitochondrial dysfunction and sarcopenia of aging: From signaling pathways to clinical trials. Int J Biochem Cell Biol 45: 22882301.

Masiero E, Agatea L, Mammucari C, Blaauw B, Loro E, Komatsu M, Metzger D, Reggiani C, Schiaffino S, Sandri M. 2009. Autophagy is required to maintain muscle mass. Cell Metab 10: 507-515.

McCully KK, Fielding RA, Evans WJ, Leigh JSJr, Posner JD. 1993. Relationships between in vivo and in vitro measurements of metabolism in young and old human calf muscles. J Appl Physiol (1985) 75: 813-819.

Mendonca GV, Pezarat-Correia P, Vaz JR, Silva L, Heffernan KS. 2016. Impact of aging on endurance and neuromuscular physical performance: The role of vascular senescence. Sports Med doi: 10.1007/s40279-016-0596-8.

Mera P, Laue K, Ferron M, Confavreux C, Wei J, Galan-Diez M, Lacampagne A, Mitchell SJ, Mattison JA, Chen Y, et al. 2016. Osteocalcin signaling in myofibers is necessary and sufficient for optimum adaptation to exercise. Cell Metab 23: $1078-1092$.

Messi ML, Li T, Wang ZM, Marsh AP, Nicklas B, Delbono O. 2016. Resistance training enhances skeletal muscle innervation without modifying the number of satellite cells or their myofiber association in obese older adults. J Gerontol A Biol Sci Med Sci 71: 1273-1280.

Metter EJ, Conwit R, Metter B, Pacheco T, Tobin J. 1998. The relationship of peripheral motor nerve conduction velocity to age-associated loss of grip strength. Aging 10: 471478.

Mikines KJ, Sonne B, Farrell PA, Tronier B, Galbo H. 1988. Effect of physical exercise on sensitivity and responsiveness to insulin in humans. Am J Physiol 254: E248-E259.

Miller BF, Olesen JL, Hansen M, Dossing S, Crameri RM, Welling RJ, Langberg H, Flyvbjerg A, Kjaer M, Babraj JA, et al. 2005. Coordinated collagen and muscle protein synthesis in human patella tendon and quadriceps muscle after exercise. J Physiol 567: 1021-1033.

Murray MP, Gardner GM, Mollinger LA, Sepic SB. 1980. Strength of isometric and isokinetic contractions: Knee muscles of men aged 20 to 86. Phys Ther 60: 412-419.

Nagasawa J, Sato Y, Ishiko T. 1991. Time course of in vivo insulin sensitivity after a single bout of exercise in rats. Int J Sports Med 12: 399-402.

Nguyen MH, Cheng M, Koh TJ. 2011. Impaired muscle regeneration in ob/ob and $\mathrm{db} / \mathrm{db}$ mice. ScientificWorld Journal 11: 1525-1535.

Nishimune H, Stanford JA, Mori Y. 2014. Role of exercise in maintaining the integrity of the neuromuscular junction. Muscle Nerve 49: 315-324.

Ono T, Isobe K, Nakada K, Hayashi JI. 2001. Human cells are protected from mitochondrial dysfunction by complementation of DNA products in fused mitochondria. Nat Genet 28: 272-275.

Orlander J, Kiessling KH, Larsson L, Karlsson J, Aniansson A. 1978. Skeletal muscle metabolism and ultrastructure 
in relation to age in sedentary men. Acta Physiol Scand 104: $249-261$.

Overend TJ, Cunningham DA, Paterson DH, Lefcoe MS 1992. Thigh composition in young and elderly men determined by computed tomography. Clin Physiol 12: 629-640.

Park SW, Goodpaster BH, Strotmeyer ES, Kuller LH, Broudeau R, Kammerer C, de Rekeneire N, Harris TB, Schwartz AV, Tylavsky FA, et al. 2007. Accelerated loss of skeletal muscle strength in older adults with type 2 diabetes: The health, aging, and body composition study. Diabetes Care 30: 1507-1512.

Payne AM, Delbono O. 2004. Neurogenesis of excitationcontraction uncoupling in aging skeletal muscle. Exerc Sport Sci Rev 32: 36-40.

Peake J, Della Gatta P, Cameron-Smith D. 2010. Aging and its effects on inflammation in skeletal muscle at rest and following exercise-induced muscle injury. Am J Physiol Regul Integr Comp Physiol 298: R1485-R1495.

Perry CG, Lally J, Holloway GP, Heigenhauser GJ, Bonen A Spriet LL. 2010. Repeated transient mRNA bursts precede increases in transcriptional and mitochondrial proteins during training in human skeletal muscle. J Physiol 588: 4795-4810.

Petersen KF, Befroy D, Dufour S, Dziura J, Ariyan C, Rothman DL, DiPietro L, Cline GW, Shulman GI. 2003. Mitochondrial dysfunction in the elderly: Possible role in insulin resistance. Science 300: 1140-1142.

Peterson MJ, Morey MC, Giuliani C, Pieper CF, Evenson KR, Mercer V, Visser M, Brach JS, Kritchevsky SB, Goodpaster BH, et al. 2010. Walking in old age and development of metabolic syndrome: The health, aging, and body composition study. Metab Syndr Relat Disord 8: 317-322.

Picard M, Ritchie D, Wright KJ, Romestaing C, Thomas MM, Rowan SL, Taivassalo T, Hepple RT. 2010. Mitochondrial functional impairment with aging is exaggerated in isolated mitochondria compared to permeabilized myofibers. Aging Cell 9: 1032-1046.

Pisot R, Marusic U, Biolo G, Mazzucco S, Lazzer S, Grassi B, Reggiani C, Toniolo L, di Prampero PE, Passaro A, et al. 2016. Greater loss in muscle mass and function but smaller metabolic alterations in older compared with younger men following $2 \mathrm{wk}$ of bed rest and recovery. J Appl Physiol (1985) 120: 922-929.

Porter C, Hurren NM, Cotter MV, Bhattarai N, Reidy PT, Dillon EL, Durham WJ, Tuvdendorj D, Sheffield-Moore M, Volpi E, et al. 2015. Mitochondrial respiratory capacity and coupling control decline with age in human skeletal muscle. Am J Physiol Endocrinol Metab 309: E224E232.

Proctor DN, Sinning WE, Walro JM, Sieck GC, Lemon PW. 1995. Oxidative capacity of human muscle fiber types: Effects of age and training status. J Appl Physiol (1985) 78: 2033-2038.

Pruchnic R, Katsiaras A, He J, Kelley DE, Winters C, Goodpaster BH. 2004. Exercise training increases intramyocellular lipid and oxidative capacity in older adults. $\mathrm{Am} \mathrm{J}$ Physiol Endocrinol Metab 287: E857-E862.

Rasmussen UF, Krustrup P, Kjaer M, Rasmussen HN. 2003. Experimental evidence against the mitochondrial theory of aging. A study of isolated human skeletal muscle mitochondria. Exp Gerontol 38: 877-886.
Raue U, Slivka D, Minchev K, Trappe S. 2009. Improvements in whole muscle and myocellular function are limited with high-intensity resistance training in octogenarian women. J Appl Physiol (1985) 106: 1611-1617.

Ringholm S, Bienso RS, Kiilerich K, Guadalupe-Grau A, Aachmann-Andersen NJ, Saltin B, Plomgaard P, Lundby C, Wojtaszewski JF, Calbet JA, et al. 2011. Bed rest reduces metabolic protein content and abolishes exercise-induced mRNA responses in human skeletal muscle. Am J Physiol Endocrinol Metab 301: E649-E658.

Romanello V, Guadagnin E, Gomes L, Roder I, Sandri C, Petersen Y, Milan G, Masiero E, Del Piccolo P, Foretz M, et al. 2010. Mitochondrial fission and remodelling contributes to muscle atrophy. EMBO J 29: 1774-1785.

Rooyackers OE, Adey DB, Ades PA, Nair KS. 1996. Effect of age on in vivo rates of mitochondrial protein synthesis in human skeletal muscle. Proc Natl Acad Sci 93: $15364-$ 15369.

Rosenberg IH. 1997. Sarcopenia: Origins and clinical relevance. J Nutr 127: 990S-991S.

Roth SM, Martel GF, Ivey FM, Lemmer JT, Tracy BL, Metter EJ, Hurley BF, Rogers MA. 2001. Skeletal muscle satellite cell characteristics in young and older men and women after heavy resistance strength training. J Gerontol A Biol Sci Med Sci 56: B240-B247.

Rowe JW, Minaker KL, Pallotta JA, Flier JS. 1983. Characterization of the insulin resistance of aging. J Clin Invest 71: $1581-1587$.

Rudrappa SS, Wilkinson DJ, Greenhaff PL, Smith K, Idris I, Atherton PJ. 2016. Human skeletal muscle disuse atrophy: Effects on muscle protein synthesis, breakdown, and insulin resistance-A qualitative review. Front Physiol 7: 361.

Safdar A, Hamadeh MJ, Kaczor JJ, Raha S, Debeer J, Tarnopolsky MA. 2010. Aberrant mitochondrial homeostasis in the skeletal muscle of sedentary older adults. PLoS ONE 5: e10778.

Sandri M, Sandri C, Gilbert A, Skurk C, Calabria E, Picard A, Walsh K, Schiaffino S, Lecker SH, Goldberg AL. 2004. Foxo transcription factors induce the atrophy-related ubiquitin ligase atrogin- 1 and cause skeletal muscle atrophy. Cell 117: 399-412.

Sandri M, Barberi L, Bijlsma AY, Blaauw B, Dyar KA, Milan G, Mammucari C, Meskers CG, Pallafacchina G, Paoli A, et al. 2013. Signalling pathways regulating muscle mass in ageing skeletal muscle: The role of the IGF1-Akt-mTORFoxO pathway. Biogerontology 14: 303-323.

Schaap LA, Pluijm SM, Deeg DJ, Harris TB, Kritchevsky SB, Newman AB, Colbert LH, Pahor M, Rubin SM, Tylavsky FA, et al. 2009. Higher inflammatory marker levels in older persons: Associations with 5-year change in muscle mass and muscle strength. J Gerontol A Biol Sci Med Sci 64: 1183-1189.

Schrager MA, Metter EJ, Simonsick E, Ble A, Bandinelli S, Lauretani F, Ferrucci L. 2007. Sarcopenic obesity and inflammation in the InCHIANTI study. J Appl Physiol (1985) 102: 919-925.

Schulte JN, Yarasheski KE. 2001. Effects of resistance training on the rate of muscle protein synthesis in frail elderly people. Int J Sport Nutr Exerc Metab 11: S111-S118. 
Schultz E, Lipton BH. 1982. Skeletal muscle satellite cells: Changes in proliferation potential as a function of age. Mech Ageing Dev 20: 377-383.

Shavlakadze T, McGeachie J, Grounds MD. 2010. Delayed but excellent myogenic stem cell response of regenerating geriatric skeletal muscles in mice. Biogerontology 11: 363-376.

Shoelson SE, Lee J, Goldfine AB. 2006. Inflammation and insulin resistance. J Clin Invest 116: 1793-1801.

Short KR, Bigelow ML, Kahl J, Singh R, Coenen-Schimke J, Raghavakaimal S, Nair KS. 2005. Decline in skeletal muscle mitochondrial function with aging in humans. Proc Natl Acad Sci 102: 5618-5623.

Slivka D, Raue U, Hollon C, Minchev K, Trappe S. 2008. Single muscle fiber adaptations to resistance training in old ( $>80$ yr) men: Evidence for limited skeletal muscle plasticity. Am J Physiol Regul Integr Comp Physiol 295: R273-R280.

Smuder AJ, Kavazis AN, Min K, Powers SK. 2011. Exercise protects against doxorubicin-induced markers of autophagy signaling in skeletal muscle. J Appl Physiol (1985) 111: 1190-1198.

Snow MH. 1977. The effects of aging on satellite cells in skeletal muscles of mice and rats. Cell Tissue Res 185: 399-408.

Sousa-Victor P, Gutarra S, Garcia-Prat L, Rodriguez-Ubreva J, Ortet L, Ruiz-Bonilla V, Jardi M, Ballestar E, Gonzalez S, Serrano AL, et al. 2014. Geriatric muscle stem cells switch reversible quiescence into senescence. Nature 506: $316-321$

Stenholm S, Harris TB, Rantanen T, Visser M, Kritchevsky SB, Ferrucci L. 2008. Sarcopenic obesity: Definition, cause and consequences. Curr Opin Clin Nutr Metab Care 11: 693-700.

Tanaka H, Dinenno FA, Monahan KD, Clevenger CM, DeSouza CA, Seals DR. 2000. Aging, habitual exercise, and dynamic arterial compliance. Circulation 102: $1270-$ 1275.

Thyfault JP, Kraus RM, Hickner RC, Howell AW, Wolfe RR, Dohm GL. 2004. Impaired plasma fatty acid oxidation in extremely obese women. Am J Physiol Endocrinol Metab 287: E1076-E1081.

Tong JF, Yan X, Zhu MJ, Du M. 2009. AMP-activated protein kinase enhances the expression of muscle-specific ubiquitin ligases despite its activation of IGF-1/Akt signaling in C2C12 myotubes. J Cell Biochem 108: 458-468.

Tonkonogi M, Fernstrom M, Walsh B, Ji LL, Rooyackers O, Hammarqvist F, Wernerman J, Sahlin K. 2003. Reduced oxidative power but unchanged antioxidative capacity in skeletal muscle from aged humans. Pflugers Arch 446: 261-269.

Tracy BL, Ivey FM, Hurlbut D, Martel GF, Lemmer JT, Siegel EL, Metter EJ, Fozard JL, Fleg JL, Hurley BF. 1999. Muscle quality. II. Effects Of strength training in 65- to 75-yr-old men and women. J Appl Physiol (1985) 86: 195-201.

Trappe S, Godard M, Gallagher P, Carroll C, Rowden G, Porter D. 2001. Resistance training improves single muscle fiber contractile function in older women. Am J Physiol Cell Physiol 281: C398-C406.

Trappe S, Gallagher P, Harber M, Carrithers J, Fluckey J, Trappe T. 2003. Single muscle fibre contractile properties in young and old men and women. J Physiol 552: 47-58.

Trounce I, Byrne E, Marzuki S. 1989. Decline in skeletal muscle mitochondrial respiratory chain function: Possible factor in ageing. Lancet 1: 637-639.

Twig G, Elorza A, Molina AJ, Mohamed H, Wikstrom JD, Walzer G, Stiles L, Haigh SE, Katz S, Las G, et al. 2008a. Fission and selective fusion govern mitochondrial segregation and elimination by autophagy. EMBO J 27: $433-$ 446.

Twig G, Hyde B, Shirihai OS. 2008b. Mitochondrial fusion, fission and autophagy as a quality control axis: The bioenergetic view. Biochim Biophys Acta 1777: 1092-1097.

Verdijk LB, Koopman R, Schaart G, Meijer K, Savelberg HH, van Loon LJ. 2007. Satellite cell content is specifically reduced in type II skeletal muscle fibers in the elderly. Am J Physiol Endocrinol Metab 292: E151-E157.

Verdijk LB, Gleeson BG, Jonkers RA, Meijer K, Savelberg HH, Dendale P, van Loon LJ. 2009. Skeletal muscle hypertrophy following resistance training is accompanied by a fiber type-specific increase in satellite cell content in elderly men. J Gerontol A Biol Sci Med Sci 64: 332-339.

Verdijk LB, Snijders T, Holloway TM, van Kranenburg J, van Loon LJ. 2016. Resistance training increases skeletal muscle capillarization in healthy older men. Med Sci Sports Exerc 48: 2157-2164.

Wild S, Roglic G, Green A, Sicree R, King H. 2004. Global prevalence of diabetes: Estimates for the year 2000 and projections for 2030. Diabetes Care 27: 1047-1053.

Yin H, Price F, Rudnicki MA. 2013. Satellite cells and the muscle stem cell niche. Physiol Rev 93: 23-67.

Zampieri S, Pietrangelo L, Loefler S, Fruhmann H, Vogelauer M, Burggraf S, Pond A, Grim-Stieger M, Cvecka J, Sedliak M, et al. 2014. Lifelong physical exercise delays age-associated skeletal muscle decline. J Gerontol A Biol Sci Med Sci 70: 163-173. 


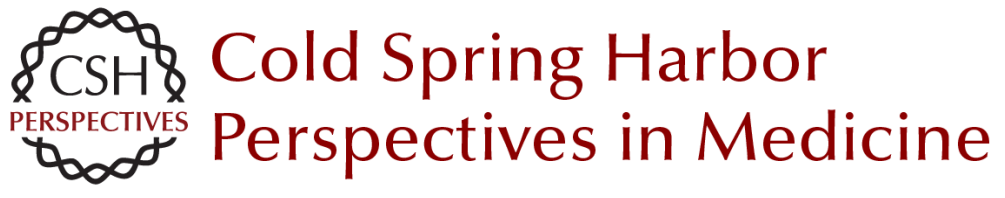

\section{Effects of Exercise and Aging on Skeletal Muscle}

Giovanna Distefano and Bret H. Goodpaster

Cold Spring Harb Perspect Med 2018; doi: 10.1101/cshperspect.a029785 originally published online April 21, 2017

\section{Subject Collection The Biology of Exercise}

Exosomes as Mediators of the Systemic

Adaptations to Endurance Exercise Adeel Safdar and Mark A. Tarnopolsky

Molecular Basis of Exercise-Induced Skeletal

Muscle Mitochondrial Biogenesis: Historical

Advances, Current Knowledge, and Future

Challenges

Christopher G.R. Perry and John A. Hawley

Exercise Metabolism: Fuels for the Fire Mark Hargreaves and Lawrence L. Spriet

Health Benefits of Exercise Gregory N. Ruegsegger and Frank W. Booth

Molecular Regulation of Exercise-Induced Muscle

Fiber Hypertrophy

Marcas M. Bamman, Brandon M. Roberts and Gregory R. Adams

Physiological Redundancy and the Integrative

Responses to Exercise Michael J. Joyner and Jerome A. Dempsey

On the Run for Hippocampal Plasticity C'iana Cooper, Hyo Youl Moon and Henriette van Praag

Molecular Basis for Exercise-Induced Fatigue: The Importance of Strictly Controlled Cellular $\mathrm{Ca}$

2+ Handling

Arthur J. Cheng, Nicolas Place and Håkan

Westerblad
Effects of Exercise and Aging on Skeletal Muscle Giovanna Distefano and Bret $H$. Goodpaster

Muscle-Adipose Tissue Cross Talk Kristin I. Stanford and Laurie J. Goodyear

Performance Fatigability: Mechanisms and Task Specificity

Sandra K. Hunter

Adaptations to Endurance and Strength Training David C. Hughes, Stian Ellefsen and Keith Baar

The Bioenergetics of Exercise

$P$. Darrell Neufer

Effects of Exercise on Vascular Function,

Structure, and Health in Humans

Daniel J. Green and Kurt J. Smith

Control of Muscle Metabolism by the Mediator

Complex

Leonela Amoasii, Eric N. Olson and Rhonda

Bassel-Duby

Theoretical and Biological Evaluation of the Link between Low Exercise Capacity and Disease Risk Lauren Gerard Koch and Steven L. Britton

For additional articles in this collection, see http://perspectivesinmedicine.cshlp.org/cgi/collection/ 